to Professor D G Oreopoulos, Division of Nephrology, Toronto Western Hospital, 399 Bathurst Street, Toronto, Ontario, Canada M5T 2S8.

\section{Information, please}

Mr M J Fields, Oral Surgery Department, Peterborough District Hospital, Peterborough PE3 6DA, would be interested to hear whether anyone has noticed an increase in aphthous ulcers in patients taking thyroxine.

The Bureau for Overseas Medical Service (BOMS) would like to hear from any wellqualified doctors returning from posts overseas who have difficulty in getting suitable appointments in Britain. Brief details should be sent to BOMS, Ross Institute, London School of Hygiene and Tropical Medicine, Keppel Street, London WC1.

\section{People in the news}

Sir James Fraser has been appointed editor of the fournal of the Royal College of Surgeons of Edinburgh.

Dr D J D Perrins is to receive the Boerema Award from the Memorial Hospital Medical Center, Los Angeles, for his contributions to the advancement of hyperbaric medicine.

Dr M L'E Orme has been awarded the 1980 Smith Kline and French Foundation biennial prize for research in clinical pharmacology for his work on oral contraceptive steroids.

The George Peter Baker prize in medicine for 1980 has been awarded at Cambridge University to Dr J A Hall.

\section{COMING EVENTS}

Wessex Rehabilitation Association Tissue Viability Group-Mceting "Problem solving in nutrition," 4 March, Salisbury. Details from C H F Blake of the
association, Rehabilitation Department, Odstock

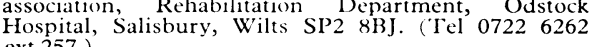
British Institute for the Study of the Arts in
Therapy-Workshops, 7-8 March, London. Details from BISAT Christchurch, 27 Blackfriars Road, London SE1 8NY.

Institute of Urology-Course "Urology for the advertisements.

Obesity symposium-Joint meeting of the Endocrine Section of the Royal Society of Medicine, the Medical and Scientific Section of the British Diabetic Association, and the Society of Endocrinology, 25-26 March, Cambridge. Details from the assistant secretary of the London W1M OBD. Closing date for applications 27 February.

Institute of Sound and Vibration Research-Details of audiology courses "Clinical audiology," 30 Marchtion, "7-11 Septrial audiology and hearing conserva14-18 September; "Auditory electrophysiology in neuro-otology," part A "Vestibular function" 15-17 June, part B "Auditory electrophysiology" $17-19$ June, Southampton, are available from Mrs G Hyde, ISVR, The University, Southampton SO

Biological Council-Symposium "Mechanisms of steroid action," 13-14 April, London. Details from Mrs College, Gower Street, London WC1E 6BT. (Please do not telephone.)

Royal Association for Disability and Rehabilitation-Workshop on developing communication in nonvocal severely physically handicapped individuals, 31 March-1 April, Brighton. Details from the conference W1N 8AB. (Tel 01-6375400, ext 220.)

International symposium on fertility control1-3 June, Tunis. Details from Dr R Mrad Dali, Service de02, Tunisia.

Royal Microscopical Society-Conference "Light microscopy '81,' 7-9 July, London. Details from the 48768/21081.) 8th World Congress of Social Psychiatry-16-22 August, Zagreb. Details from the congress secretariat, University Department of Neurology, Psychiatry, University Hospital, Vinogradska 29, 41000 Zagreb, Yugoslavia.

Society of Community Medicine-Details of two, symposia, "Hearing impairment in the young and old," L June, and "Retire- and live," 28 September, strative secretary of the society, 28 Portland Place, strative secretary of the society, 28
London W1N 41)E. (1 el $01-5802731$.)

2nd Yugoslav symposium on "Amylblyopia and strabismus"-28-30 September, Zadar. Details from Prim dr Bogomir Smrkinić, Medicinski centar, $1 \mathrm{G}$
Kovaćića 1, 57000 Zadar, Yugoslavia.

\section{SOCIETIES AND LECTURES}

For attending lectures marked $*$ a fee is charged or a ticket is required. Applications should be made first to the
institutions concerned.

Monday, 16 February

Institute of Dermatology-4.45 pm, Dr J Pegum: The apocrine glands, structure and function. INSTITUTE of NELRology-5.30 pm, Professor G $\mathrm{M}$
McKhann (Johns Hopkins): Cellular approach to
neurological disease. neurological disease.

INSTITUTE OF OBSTETRICS AND GYNAECOLOGY-12.30 pm, Dr A F Swain: Skin diseases in pregnancy.

OYAL COLlEGE OF SURGEONS OF ENGLAND-5 pm, Hunterian oration by Sir Reginald Murley: Peace and
strife in Hunter's time.

ROYAL FREE HOSPITAL SCHOOL OF MEDICINE-At Royal Free Hospital, 2 pm,
Adventures in liver land.

\section{Tuesday, 17 February}

UNIVERSITY OF LONDON-At Queen Mary College, $5.15 \mathrm{pm}$, special university lecture by Professor B $M$ of parental rights.

\section{Wednesday, 18 February}

InSTITUTE OF DeRmatology-4.45 pm, Dr R A J Eady : The mast cell.

INSTITUTE OF Neurology, QueEN SQuare-Sandoz Fundation lectures 6 pm by Dr I J Russell: Recepto potentials and frequency selectivity in cochlear hair
cells. 7 pm, Dr J D Hood: Audiological considerations in sensory neural hearing loss.

INSTITUTE OF ORTHOPAEDICS-Cerebral palsy-selection of patients, $6 \mathrm{pm}, \mathrm{Mr}$ B A Roper: Upper limb. $7 \mathrm{pm}$, of patients, $6 \mathrm{pm}, \mathrm{Mr} \mathrm{B}$ A

MIDLAND MEDICAL SOCIETY-At Birmingham Medica Institute, 8.15 pm, joint meeting with the BMA's Birmingham Division, Mr J R Bettinson: It is not now $7.15 \mathrm{pm}^{*}$ )

RoYal FREe Hospital $-5 \mathrm{pm}$, Dr J A H Wass: Pituitary disorders.

UNIVERSITY OF OXFORD-At John Radcliffe Hospital, $5 \mathrm{pm}$, Professor Roy Calne: Cyclosporin A and organ transplantation.

\section{Thursday, 19 February}

INSTITUTE OF OBSTETRICS AND GYNAECOLOGY $-5 \mathrm{pm}$, Beecham lecture by Professor J H M Pinkerton: Pioneers of fetal auscultation.
KING'S College London-1.15 pm, Dr A W Clare: Abuse of alcohol.

\section{Friday, 20 February}

Faculty of the History and Philosophy of Medicine AND PHARMACY OF THE WORSHIPFUl SOCIETY OF APOTHECARIES OF LONDON-5.30 for $6 \mathrm{pm}$, John
Locke lecture by Sir John Butterfield: The function of criticism.

INSTITUTE OF LARYNGOLOGY AND OTOLOGY $-5.30 \mathrm{pm}$, Mr J C M Currie: Fractures at the base of the skull.

OYAL COLLEGE OF SURGEONS OF EDINBURGH-4.30 pm, William Guy memorial lecture by $\mathrm{Mr}$

Ankylosis of the temporomandibular joint.
UNIVERSITY OF LIVERPOOL-At Royal Liverpool NIVERSITY OF LIVERPOOL-At Royal Liverpool ment of peripheral nerve injuries in the upper limb.
ment

\section{Saturday, 21 February}

Midland Thoracic SociETy-At Birmingham Medical Institute, 11 am, Dr D M Denison: The chest in flying and diving. (Followed by lunch.* Guests
invited.)

UNIVERSITY OF LIVERPOOL-At Royal Liverpool Hospital, 9 am, Mr D M Brooks: Recent advances in reconstructive surgery in the hand. UNIVERSITY OF OXFORD-At Nuffield Orthopaedic chemistry of fracture repair. $9.30 \mathrm{am}$, Dr C G Woods: Histopathology of fracture repair.

\section{BMA NOTICES}

\section{Central Meetings}

FEBRUARY

19 Thurs General Medical Services Committee, 10
24 Tues

27 Fri

Doint Consultants Committee (7 7QP), $10.15 \mathrm{am}$. Honorary Secretaries Conference, $10 \mathrm{am}$. Executive Subcommittee (CCCM), 10.30 am.

4 Wed Council, 10 am.

Medical Academic Staff Committee, 10.30 General Purposes Subcommittee (CCHMS), $10 \mathrm{am}$.

\section{Division Meetings}

Members proposing to attend meetings marked * are asked
to notify in advance the honorary secretary concerned. Aberystwyth-At Bronglais General Hospital, Tuesday, 17 February, 8 pm, Dr Guan S Lee: "Acu-

puncture," (Guests invited.) Hospital, Thursday, 19 February, 8 for $8.30 \mathrm{pm}$, annual Birmingham-At Birmingham Medical Institute, Wednesday, 18 February, $8.15 \mathrm{pm}$, joint meeting with the Midland Medical Society, speaker Mr J R Bettinson:
"It is not now as it hath been of yore..." (Preceded by
buffet supper, 7.15 pm.*)

Bradford and Airedale-At Bradford Royal Infirmary, Wednesday, 18 February, 8 pm, joint meeting with the Bradford Medico-chirurgical Society, speaker Professor H A F Dudley: "Reflections on the surgical life." (Guests welcome.)
Bromley-At Farnborough Hospital, Friday, 20 February, 8 pm, Burgundy wine tasting with buffet.* Croydon-At Conservative Club, Tuesday, 17 February, $8 \mathrm{pm}$, annual joint meeting with Croydon dentists, supper, speaker Dr David Paul: "Forensic medicine-the non dead."* (Guests are invited.)

Halifax-At Halifax General Hospital, Wednesday,
18 February, 8.15, pm, Mr A W Goode: "Man and Hastings-At Stables Theatre, Tuesday, 17 Hastings-At Stables Theatre, Tuesday, 17
February, $7.15 \mathrm{pm}$, musical evening with the Kingsland February, $7.15 \mathrm{pm}$, musical evenin
Singers.* (Please bring guests.)

Singers.* (Please bring guests.) 20 February, 7.30 for $8 \mathrm{pm}$, annual dinner dance held jointly with the Lancaster and Morecambe Section of the British Dental Association.* (Guests invited.)
Northallerton-At Friarage Hospital, Friday, 20 Northallerton-At Friarage Hospital, Friday, 20 Renfrewshire-At Royal Alexandra Infirmary, Paislcy, Sunday, 22 February, 10.30 for 11 am, symposium "Handicap-the young and the old." * South Warwickshire-At Warwick Hospital,
Wednesday, 18 February, 7.30 for 8 pm, joint meeting
with junior hospital staff, lecture by Dr M Aslam: "Mith junior hospital staff, ${ }^{2}$ (Followed by wine and cheese party.)

Waltham Forest-At Whipps Cross Hospital, "Dermatology in the 80 s.",* (Preceded by supper 7.30 pm.* (juests invited.)

Wigtown-At Judge's Keep Hotel, liriday, 20 Wigtown-At Judge's Keep Hotel, Friday, 20
February, 7.30 for 8 pm, M J G Pollock: "Limb Wolverhampton-At Wolverhampton Masonic Club, Friday, 20 February, 7.30 for $8 \mathrm{pm}$, medical dinner.* (Guests are invited.)
Worcester and Bromsgrove-At Gifford Hotel Friday, 20 February, 7.45 for $8.15 \mathrm{pm}$, joint dinner with
BDA.*

\section{UNIVERSITIES AND COLLEGES}

\section{LONDON}

The title of professor of clinical pharmacology has been conferred on Dr A Richens in respect of his post at the urology.

MD-D B O'Keeffe, Lindsay J Webb, M J World.

MS-R E Jenner.

\section{CONSULTANT APPOINTMENTS}

BIRMINGHAM AHA(T)-Dr C Bainton (psychiatrist).

CAMBridgeshire AHA(T)-Mr D A Moffat (ENT surgery); Dr T W Higenbot
Dr J P Newell (anaesthetics).

\section{Correction}

We regret that in the report of the board of the Faculty of Anaesthetists of the Royal College of Surgeons of England the name of Dr T E J Healy was inadvertently omitted. He was appointed faculty regional educational
adviser in the Trent region. We also regret that Dr adviser in the Trent region. We also reg
Catherine $R$ Grebenik's name was misspelt.

(1) British Medical Journal 1981

All Rights Reserved. No part of this publication may be reproduced, stored in a retrieval system, or transmitted, in any form or by any means, electronic, mechanical,
photocopying, recording or otherwise, without the prior permission of the British Medical fournal. 